\title{
KONFLIK PENGUASAAN TANAH PERKEBUNAN
}

\author{
Herawan Sauni \\ Faculty of Law University of Bengkulu \\ Email:profherawan@gmail.com
}

\begin{abstract}
There is a vivid imbalance in farm land domination. This emerge conflict in almost Indonesia territory. Structuring the ownership or control of land has been started since the Act Numebr 5 of 1960 as the reference in the structuring of the agricultural land holdings in Indonesia. However, what is hoped and be the justification reason the act seems has not shown as demanded. Based on Decree of Head of BPN RI Number 34 of 2007 on Technical Guidelines for Handling and Resolution of Land Issues, land conflicts arise regarding the issue of tenure, ownership, use or utilization of the plot of land. The enactment of Law No. 18 of 2004 on Plantations also open conflicts between farmers and plantation companies. Conflict occurs when the plantation is difference between one or more people or groups of people with plantation companies relating to land tenure estates. There are several factors that cause conflict, especially agricultural land tenure plantation land, namely: (1) inequality of agricultural land holdings; (2) there is a vagueness setting land rights; (3) wasteland physically; and (4) overlapping land ownership. Recalling the complexity of the conflict over land, land conflict resolution should be based not only on purely formal legal approach but also through other approaches such as economic, social and cultural.
\end{abstract}

Keywords: Conflict, land domination, plantation

\begin{abstract}
ABSTRAK
Ada ketidakseimbangan yang jelas dalam dominasi lahan pertanian. Ini menimbulkan konflik di hampir wilayah Indonesia. Penataan kepemilikan atau penguasaan tanah sudah dimulai sejak UU No. 5 tahun 1960 sebagai acuan dalam penataan kepemilikan tanah pertanian di Indonesia. Namun, apa yang diharapkan dan menjadi alasan pembenaran tindakan itu tampaknya belum muncul sesuai tuntutan. Berdasarkan Keputusan Kepala BPN RI Nomor 34 Tahun 2007 tentang Pedoman Teknis Penanganan dan Penyelesaian Masalah Pertanahan, konflik tanah timbul terkait masalah penguasaan, kepemilikan, penggunaan atau pemanfaatan sebidang tanah. Diundangkannya UU No. 18 tahun 2004 tentang Perkebunan juga membuka konflik antara petani dan perusahaan perkebunan. Konflik terjadi ketika perkebunan itu berbeda antara satu atau lebih orang atau kelompok orang dengan perusahaan perkebunan yang berkaitan dengan perkebunan. Ada beberapa faktor yang menyebabkan konflik, terutama lahan pertanian kepemilikan lahan perkebunan, yaitu: (1) ketidaksetaraan kepemilikan lahan pertanian; (2) ada ketidakjelasan pengaturan hak atas tanah; (3) gurun secara fisik; dan (4) kepemilikan tanah yang tumpang tindih. Mengingat kompleksitas konflik atas tanah, resolusi konflik tanah harus didasarkan tidak hanya pada pendekatan hukum formal semata tetapi juga melalui pendekatan lain seperti ekonomi, sosial dan budaya.
\end{abstract}

Kata kunci: Konflik, penguasaan lahan, perkebunan 
Pendahuluan

Fakta empiris menunjukkan bahwa sampai saat ini kebanyakan penduduk Indonesia masih menggantungkan hidupnya dari usaha disektor pertanian. Sebagian besar penduduk Indonesia masih tinggal di perdesaan dan bekerja sebagai petani, baik sebagai petani pemilik tanah pertanian maupun sebagai penggarap tanah atau buruh tani. Namun sayangnya kebanyakan petani Indonesia adalah petani yang tidak mempunyai tanah. Kalaupun mempunyai tanah pada umumnya hanya memiliki atau menguasai tanah yang sangat sempit atau bahkan sama sekali tidak mempunyai tanah pertanian. Seyogyanya ketika seseorang mempunyai mata pencaharian sebagai petani, maka idealnya petani dimaksud mempunyai lahan pertanian yang luasnya cukup memadai. Sebab dari usaha tani itulah seorang petani akan memenuhi kebutuhan hidupnya, seperti kebutuhan sandang, pangan, papan, termasuk untuk biaya pendidikan anak-anaknya. Dengan luasan lahan pertanian yang memadai maka dapat mengangkat status sosial yang akan mensejajarkan pekerjaan petani dengan profesi yang lainnya, seperti Pegawai Negeri, pengusaha, dan lain-lain, yang pada akhirnya pemerataan kesejahteraan antar sektor dan antar profesi akan dapat terwujud.
Kondisi yang ideal tersebut sesungguhnya merupakan cita-cita bangsa ini ketika pertama kali menancapkan suatu upaya untuk memperbaiki struktur penguasaan tanah pertanian pada awal kemerdekaan bangsa Indonesia. Upaya tersebut bukan tanpa alasan, sebab pada awal kemerdekaan bangsa ini kondisi penguasaan tanah pertanian sebagai akibat dari penjajahan kolonial adalah sangat tidak ideal dan cendrung tidak adil. Terdapat ketimpangan yang begitu tajam dalam penguasaan tanah pertanian, terjadi konflik penguasaan tanah hampir diseluruh wilayah negeri ini. Kondisi yang demikian itu menjadikan alasan perlu dilakukan perbaikan dan penataan penguasaan tanah di Indonesia. Upaya penataan penguasaan tanah tersebut ditandai dengan lahirnya UUPA yang kelahirannya mengalami proses berliku dan penuh dengan perdebatan serta memakan waktu yang cukup panjang (1948-1960). UUPA ini dimaksudkan akan menjadi acuan dalam penataan struktur penguasaan tanah pertanian di Indonesia. Dengan UUPA ini diharapkan akan tercipta suatu kondisi yang ideal dalam penguasaan tanah pertanian bagi petani, dengan prinsip dasar tanah pertanian untuk petani.

Akan tetapi apa yang dicita-citakan dan menjadi dasar pembenaran (justication) lahirnya UUPA tersebut nampaknya sampai 
saat ini belum menunjukkan hasil sebagaimana yang diinginkan. Berdasarkan hasil sensus pertanian tahun 2013 menunjukkan bahwa usaha pertanian di Indonesia didominasi oleh jenis usaha rumah tangga. Hal ini tercermin dari besarnya jumlah rumah tangga usaha pertanian jika dibandingkan dengan perusahaan pertanian berbadan hukum atau jenis usaha pertanian lainnya, yaitu selain rumah tangga dan perusahaan pertanian berbadan hukum. Jumlah rumah tangga usaha pertanian di Indonesia hasil ST 2013 tercatat sebanyak 26,14 juta rumah tangga, menurun sebesar 16,32 persen dari hasil Sensus Pertanian 2003 (ST 2003) yang tercatat sebanyak 31,23 juta rumah tangga. Sedangkan jumlah perusahaan pertanian berbadan hukum hasil ST 2013 tercatat sebanyak 4.165 perusahaan dan jenis usaha pertanian lainnya sebanyak 5.922 unit dan terjadi peningkatan 3,87 persen dari sensus pertanian tahun $2003^{1}$.

"Apabila diklasifikasikan menurut golongan luas lahan, pada tahun 2003 terlihat bahwa jumlah rumah tangga usaha pertanian yang menguasai lahan kurang dari $0,50 \mathrm{Ha} \quad\left(5.000 \quad \mathrm{~m}^{2}\right)$ mendominasi jumlah rumah tangga usaha pertanian di Indonesia. Kondisi yang hampir serupa terjadi pada tahun 2013. Tercatat bahwa pada tahun 2013, jumlah rumah tangga usaha pertanian dengan luas lahan yang dikuasai kurang

1 Badan Pusat Statistik, Laporan Hasil Sensus Pertanian Tahun 2013, hal. 1 dari $0,10 \mathrm{Ha}\left(1.000 \mathrm{~m}^{2}\right)$ adalah sebesar 4,34 juta rumah tangga, mengalami penurunan sebesar 53,75 persen dibandingkan tahun 2003, yang tercatat sebanyak 9,38 juta rumah tangga. Rumah tangga usaha pertanian dengan luas lahan yang dikuasai antara 0,10-0,19 $\mathrm{Ha}$ (1.000-1.999 $\mathrm{m}^{2}$ ) pada tahun 2013 adalah sebanyak 3,55 juta rumah tangga, menurun sebesar 1,45 persen bila dibandingkan dengan tahun 2003 yang tercatat sebanyak 3,6 juta rumah tangga. Golongan luas lahan 0,20-0,49 Ha (2.000-4.999 $\left.\quad \mathrm{m}^{2}\right)$ tercatat mempunyai jumlah rumah tangga usaha pertanian sebanyak 6,73 juta rumah tangga pada ST2013, menurun sebanyak 83,58 ribu rumah tangga jika dibandingkan tahun 2003. Sedangkan untuk golongan luas lahan yang dikuasai lebih dari $0,50 \mathrm{Ha}\left(5.000 \mathrm{~m}^{2}\right)$, jumlah usaha rumah tangga pertanian hasil ST2013 sedikit meningkat dibandingkan dengan hasil ST2003. Untuk rumah tangga usaha pertanian dengan luas lahan lebih dari 0,50 Ha hasil ST2003 adalah sebanyak 11,43 juta rumah tangga. Angka ini sedikit meningkat (0,70 persen) pada ST 2013, yaitu menjadi sebanyak 11,51 juta rumah tangga. Hal yang menarik untuk dicermati adalah pada data tersebut masih terdapat rumah tangga usaha pertanian yang menguasai lahan kurang dari 0,10 Ha pada ST 2013, meskipun jumlahnya menurun tajam dibanding ST $2003^{2}$.

Rumah tangga usaha pertanian pengguna lahan ternyata mendominasi rumah tangga usaha pertanian di Indonesia. Dari sebanyak 26,14 juta rumah tangga usaha pertanian di Indonesia, sebesar 98,53 persen

\footnotetext{
${ }^{2}$. Ibid. hal. 11-14
} 
merupakan rumah tangga usaha pertanian pengguna lahan (25,75 juta rumah tangga). Sedangkan rumah tangga usaha pertanian bukan pengguna lahan hanya sebesar 1,47 persen, atau sebanyak 384 ribu rumah tangga.

Rumah tangga pertanian pengguna lahan dapat digolongkan ke dalam dua kelompok besar, yaitu rumah tangga petani gurem (rumah tangga usaha pertanian pengguna lahan yang menguasai lahan kurang dari $0,50 \mathrm{Ha}$ ) dan rumah tangga bukan petani gurem (rumah tangga usaha pertanian pengguna lahan yang menguasai lahan 0,50 Ha atau lebih). Hasil ST 2013 menunjukkan bahwa dari sebesar 98,53 persen rumah tangga usaha pertanian pengguna lahan, sebesar 55,33 persennya $(14,25$ juta rumah tangga) merupakan rumah tangga petani gurem, sedangkan rumah tangga bukan petani gurem sebesar 44,67 persen $(11,50$ juta rumah tangga).

Data tersebut menjelaskan bahwa ternyata jumlah rumah tangga yang masih menggantungkan hidupnya dari usaha pertanian tetap tinggi, meskipun jika dibandingkan dengan sensus pertanian tahun 2003 terjadi penurunan. Data tersebut tidak menjelaskan mengapa terjadi penurunan dan apa yang menjadi faktor penyebab, serta sektor mana yang menjadi pilihan mata pencaharian 16, 32 persen tersebut. Sementara itu pada perusahaan pertanian yang berbadan hukum terjadi peningkatan 3,87 persen. Perusahaan pertanian tersebut adalah perusahaan-perusahan yang bergerak dibidang pertanian dalam arti luas, seperti perkebunan, peternakan, dan perikanan dengan fasilitas Hak Guna Usaha yang tentunya memerlukan lahan yang sangat luas. Oleh karena itu kenaikan 3,87 persen pada golongan ini mempunyai pengaruh yang sangat besar terhadap penggunaan dan penguasaan lahan pertanian.

Menarik untuk dicermati bahwa dari jumlah rumah tangga pertanian 26,14 juta rumah tangga usaha pertanian di Indonesia, sebesar 98,53 persen (25, 75 juta RTP) merupakan RTP pengguna lahan. Sedangkan rumah tangga usaha pertanian bukan pengguna lahan hanya sebesar 1,47 persen (384 ribu RTP). Lebih lajut dari 25, 75 juta RTP pengguna lahan, sebesar 55,33 persennya (14,25 juta rumah tangga) merupakan rumah tangga petani gurem, sedangkan rumah tangga bukan petani gurem sebesar 44,67 persen (11,50 juta rumah tangga). Data ini menunjukkan bahwa kebanyakan petani kita adalah tergolong petani yang mempunyai lahan kurang dari 0,50 Hektar dan tergolong sebagai petani gurem. Kondisi ini mirip dengan keadaan petani kita pada awal kemerdekaan. Peta penguasaan tanah yang 
demikian sekaligus juga membuktikan upaya perbaikan struktur penguasaan tanah pertanian di Indonesia sampai saat ini belum membuahkan hasil yang memadai kalau tidak boleh dikatakan gagal.

Tetapi pada sisi yang lain ada sekelompok kecil penduduk menguasai tanah yang sangat luas. Termasuk dalam kelompok ini adalah perusahaan-perusahaan besar seperti Hak Pengusahaan Hutan (HPH) dan perusahaan-perusahaan besar yang bergerak disektor perkebunan dengan fasilitas HGU. Perusahaan-perusahaan dimaksud menguasai lahan pertanian yang sangat luas sampai jutaan hektar'3 Selain dari kelompok perusahaan tersebut di atas, akhir-akhir ini yang menambah penyebab semakin terbatasnya akses petani dalam penguasaan tanah pertanian yaitu semakin berkembangnya usaha pertambangan yang menguasai lahan yang sangat luas, terutama perusahaan yang bergerak dibidang pertambangan batu bara. Keberadaan usaha pertambangan besar tersebut sangat berpengaruh terhadap penguasaan lahan pertanian. Bahkan keberadaan usaha-usaha tersebut di atas menyebabkan terjadinya alih fungsi tanah pertanian menjadi non pertanian.

${ }^{3}$ Dianto Bacriadi dan Noer Fauzi, Pembaharuan Agraria (Agrarian Reform) Adalah Agenda yang inklusif Dengan Reformasi Sosial Secara Menyeluruh, Suara pembaruan Agraria No.4 Bandung, 1998, hal. 11.
Data singkat tersebut ingin mendeskripsikan bahwa dibidang agraria kesenjangan atau ketidakadilan dalam penguasaan tanah di negeri ini sudah sedemikian parah. Berdasarkan pengamatan sementara salah satu dari banyak faktor yang menjadi penyebab utama terjadinya konflik agraria (lebih konkretnya pertanahan) sampai saat ini adalah adanya ketimpangan penguasaan atau pemilikan tanah pertanian (dalam arti luas), distribusi sumber penghidupan berupa tanah yang tidak proporsional.

\section{Analisis dan Disukusi}

\section{Konflik Penguasaan Tanah Pertanian}

Konflik penguasaan tanah Indonesia sesungguhnya telah ada sejak zaman kolonial berkuasa di Indonesia, konflik terus berlangsung setelah Indonesia merdeka. Kemudian seiring dengan perjalanan bangsa ini termasuk kehidupan politiknya yang penuh dengan dinamika. Mulai dari rezim orde lama, orde baru, orde reformasi dan pasca reformasi, telah mewarnai konflik penguasaan tanah di negeri ini, baik dari segi kwalitas maupun kwantitas konflik ada kecendrungan semakin menunjukkan peningkatan.

Konflik merupakan suatu gejala yang umumnya muncul sebagai akibat dari interaksi manusia dalam hidup bermasyarakat. Konflik 
akan timbul ketika terjadi persaingan baik individu maupun kelompok. Konflik juga bisa dipicu karena adanya perbedaan pendapat antara komponen-komponen yang ada di dalam masyarakat membuatnya saling mempertahankan ego dan memicu timbulnya pertentangan.

Berdasarkan uraian tersebut di atas dapat disimpulkan bahwa konflik adalah pertentangan antara satu orang atau lebih atau kelompok dengan satu atau lebih orang dan kelompok mengenai sesuatu obyek nilai, benda, atau urusan dengan tujuan untuk memperoleh pengakuan, kekuasaan, atau hak, dalam mewujudkan tujuan tersebut kadangkadang dilakukan dengan kekerasan.

Konflik biasanya terkait dengan individu atau kelompok lain, oleh karena itu sering disebut dengan konflik sosial. Berdasarkan Undang-Undang Nomor 7 Tahun 2012 tentang Penanganan Konflik Sosial, yang dimaksud dengan Konflik Sosial adalah perseteruan dan/atau benturan fisik dengan kekerasan antara dua kelompok masyarakat atau lebih yang berlangsung dalam waktu tertentu dan berdampak luas yang mengakibatkan ketidakamanan dan disintegrasi sosial sehingga mengganggu stabilitas nasional dan menghambat pembangunan nasional.

Sementara itu yang menjadi pemicu konflik sosial sendiri dapat bersumber dari beberapa aspek kehidupan antara lain berkaitan dengan; a) permasalahan politik, ekonomi, dan sosial budaya, b) sengketa batas wilayah desa, kabupaten/kota, dan/atau provinsi, c. penguasaan sumber daya alam baik secara vertical maupun horizontal ${ }^{4}$.

Menurut Keputusan Kepala BPN RI Nomor 34 Tahun 2007 Tentang Petunjuk Teknis Penanganan dan penyelesaian Masalah Pertanahan, konflik adalah perbedaan nilai, kepentingan, pendapat dan atau persepsi antara warga atau kelompok masyarakat dengan badan hukum (privat atau publik), masyarakat dengan masyarakat mengenai status penguasaan dan atau status kepemilikan dan atau status penggunaan atau pemanfaatan atas bidang tanah tertentu oleh pihak tertentu, serta mengandung aspek politik, ekonomi dan sosial budaya ${ }^{5}$.

Sedang perkebunan menurut Undangundang Nomor 18 Tahun 2004 Tentang perkebunan adalah segala kegiatan yang mengusahakan tanaman tertentu pada tanah dan/atau media tumbuh lainnya dalam ekosistem yang sesuai,

\footnotetext{
${ }^{4}$ Rapim Polri, Identifikasi potensi konflik yang bersumber dari sara, industri, economy gap, masalah ketenagakerjaan dan dampak industri perkebunan serta upaya penanggulangannya secara efektif, "Makalah", Jakarta, 30 Januari 2013.

${ }^{5}$ Keputusan Kepala BPN RI Nomor 34 Tahun 2007 Tentang Petunjuk Teknis Penanganan dan penyelesaian Masalah Pertanahan
} 
mengolah dan memasarkan barang dan jasa hasil tanaman tersebut, dengan bantuan ilmu pengetahuan dan teknologi, permodalan serta manajemen untuk mewujudkan kesejahteraan bagi pelaku usaha perkebunan dan masyarakat.

Sedangkan perusahaan perkebunan adalah pelaku usaha perkebunan warga negara Indonesia atau badan hukum yang didirikan menurut hukum Indonesia dan berkedudukan di Indonesia yang mengelola usaha perkebunan dengan skala tertentu.

Berdasarkan pengertian perkebunan tersebut yang dimaksudkan konflik perkebunan dalam tulisan ini adalah pertentangan antara satu orang atau lebih atau kelompok rakyat dengan perusahaan perkebunan yang berkaitan dengan penguasaan tanah perkebunan. Konflik tersebut dapat berwujud penyerobotan tanah, penjarahan hasil tanaman, atau pengrusakan sarana dan prasarana perusahaan perkebunan.

Dalam bagian ini tidak bermaksud menguraikan konsep konflik secara mendalam. Uraian singkat mengenai pengertian konflik tersebut hanya ingin menjelaskan bahwa ada persoalan kemasyarakatan terkait dengan penguasaan tanah pertanian. Masyarakat termasuk juga petani berupaya sekuat mungkin untuk memperoleh sumber penghidupan yang berupa tanah. Dalam upaya meperoleh tanah pertanian dimaksud kadang-kadang dilakukan dengan cara-cara yang tidak lazim dan unprosedural. Akibat perilaku yang demikian tidak jarang menimbulkan gesekan-gesekan dalam masyarakat dan tidak jarang pula menimbulkan kekerasan yang berdampak pada kerugian harta benda bahkan mengorban jiwa orang lain.

Dalam bagian akhir dari tulisan ini akan membahas mengenai faktor-faktor yang menjadi penyebab terjadinya konflik penguasaan tanah pertanian khususnya tanah perkebunan. Dalam bagian ini akan mencoba mengurai beberapa faktor yang menjadi akar masalah yang menjadi pemicu terjadinya konflik tanah perkebunan, terutama konflik yang muncul terkini.

Menurut hemat kita paling tidak terdapat beberapa faktor yang menjadi penyebab maraknya konflik penguasaan tanah perkebunan akhir-akhir ini, yaitu:

\section{Ketimpangan Penguasaan Tanah Pertanian \\ Secara umum yang menjadi} penyebab utama konflik penguasaan tanah perkebunan adalah karena semakin dalamnya ketimpangan penguasaan tanah pertanian. Pada satu sisi petani yang memang mata pencaharian pokoknya 
hidup dari usaha pertanian hanya memiliki tanah yang sangat sempit atau bahkan tidak punya tanah pertanian sama sekali, tetapi pada sisi yang lain ada segelintir kelompok orang yang bukan petani atau badan hukum menguasai tanah yang sangat luas. Kondisi ini telah berlangsung cukup lama. Adanya kelompok masyarakat tertentu apapun sebutannya menyebabkan akses petani untuk menguasai tanah pertanian semakin lama semakin terbatas.

Dalam kerangka memenuhi kebutuhan hidup keluarga petani dimaksud, maka petani berupaya untuk menguasai (ocupasi) lahan pertanian yang telah duikuasai oleh pelaku usaha dibidang perkebunan, tertutama perkebunan-perkebunan besar yang menguasai lahan yang sangat luas. Tindakan ini biasanya dilakukan tidak sendiri-sendiri melainkan dilakukan secara massal. Masyarakat berupaya untuk menguasai lahan perkebunan baik yang telah diolah maupun yang belum. Mereka seolah-olah telah mengabaikan norma-norma yang berlaku. Hal ini diperparah dengan sikap pemerintah yang kadang-kadang lamban didalam mencegah perilaku masyarakat dan bahkan terkesan membiarkan perbuatan tersebut berlangsung. Kondisi yang demikian ini bisa dikatakan terjadi diseluruh provinsi di Indonesia. Bahkan implikasi dari perbuatan tersebut telah menimbulkan dampak yang tidak menguntungkan bagi para pihak.

Tindakan penguasaan tanah perkebunan yang telah dikusai dengan sesuatu hak yang sah oleh pihak-pihak yang tidak berhak tersebut apapun alasannya adalah perbuatan yang tidak dapat dibenarkan dan secara yuridis termasuk perbuatan yang melanggar hukum. Sebab untuk memperoleh hak-hak atas tanah haruslah dilakukan berdasarkan pada alas hak dan menurut tata cara yang telah diatur dalam peraturan perundangundangan. Selain itu juga dalam konsep hukum agrarian, tidak istilah tanah yang tidak bertuan yang dengan bebas untuk dikuasai. Untuk menguasai atau memiliki tanah apapun statusnya telah diatur oleh hukum. Demikian juga tata cara untuk memperoleh hak tersebut haruslah dilakukan dengan cara sebagaimana yang telah diatur menurut hukum yang berlaku.

Ketimpangan penguasaan tanah tersebut terjadi karena tidak berjalannya program pembaruan agraria sebagaimana diamanatkan UUPA. Filosofi dari keluarnya UUPA untuk terciptanya 
keadilan dibidang penguasaan tanah pertanian ternyata tidak dipahami secara benar, baik pada tataran legislasi maupun pada tataran implementasi undang-undang tersebut. Adanya pada pasal-pasal yang memuat asas-asas yang terkandung didalamnya belum terimplemntasi dengan benar; misalnya asas keadilan, asas manfaat, asas usaha bersama, asas persamaan hak, asas ketuhanan, asas fungsi sosial, asas tanah untuk pertanian belum terimplementasi dengan baik.

Implikasinya adalah terjadi penguasaan tanah secara lantifundias, terjadinya fragmentasi tanah, timbulnya tuna kisma, pemilikan tanah secara guntai semakin meningkat, pemilikan tanah pertanian oleh bukan petani, timbulnya tanah terlantar secara fisik. Kondisi ini semua sebagai akibat tidak berhasilnya kita di dalam melaksanakan program reformasi pertanahan.

\section{Terdapat Kekaburan Pengaturan Hak} Guna Usaha

Hak guna-usaha adalah hak untuk mengusahakan tanah yang dikuasai langsung oleh Negara dalam jangka waktu paling lama 25 tahun dan dapat diperpanjang 25 tahun lagi. Untuk tanaman tertentu seperti tanaman kelapa sawit Hak Guna Usaha dapat diberikan dengan jangka waktu paling lama 35 tahun dan dapat diperpanjang 25 tahun lagi. Peruntukkan Hak Guna Usaha digunakan untuk keperluan perusahaan pertanian, perikanan atau peternakan. Hak guna-usaha diberikan atas tanah yang luasnya paling sedikit 5 hektar, dengan ketentuan bahwa jika luasnya 25 hektar atau lebih harus memakai investasi modal yang layak dan teknik perusahaan yang baik, sesuai dengan perkembangan zaman. Hak guna-usaha terjadi karena penetapan Pemerintah.

Pengaturan tetangan hak guna usaha ini diatur dalam UUPA dan Peraturan Pemerintah Nomor 40 Tahun 1996 tentang Hak Guna Usaha, Hak Guna Bangunan, dan Hak Pakai. Berkaitan dengan penguasaan tanah dengan status penguasaan tanah dengan hak guna usaha adalah berkaitan dengan obyek, luas, serta alas hak tanah yang diberikan dengan hak guna usaha.

Berkaitan dengan obyek hak guna usaha, dalam Pasal 28 ayat (1) UUPA disebutkan bahwa hak guna-usaha adalah hak untuk mengusahakan "tanah yang dikuasai langsung oleh Negara". Selanjutnya dalam Pasal 4 PP No. 40 Tahun 1996 disebutkan kembali bahwa: 
Tanah yang dapat diberikan dengan Hak Guna Usaha adalah tanah Negara : (1) Dalam hal tanah yang akan diberikan dengan Hak Guna Usaha itu adalah tanah Negara yang merupakan kawasan hutan, maka pemberian Hak Guna Usaha dapat dilakukan setelah tanah yang bersangkutan dikeluarkan dari statusnya sebagai kawasan hutan : (2) Pemberian Hak Guna Usaha atas tanah yang telah dikuasai dengan hak tertentu sesuai ketentuan yang berlaku, pelaksanaan ketentuan Hak Guna Usaha tersebut baru dapat dilaksanakan setelah terselesaikannya pelepasan hak tersebut sesuai dengan tata cara yang diatur dalam peraturan perundang-undangan yang berlaku : (3) Dalam hal di atas tanah yang akan diberikan dengan Hak Guna Usaha itu terdapat tanaman dan/atau bangunan milik pihak lain yang keberadaannya berdasarkan alas hak yang sah, pemilik bangunan dan tanaman tersebut diberi ganti kerugian yang dibebankan pada pemegang Hak Guna Usaha baru.

Dari bunyi ketentuan tersebut di atas sangat jelas bahwa pada asasnya yang menjadi obyek hak guna usaha adalah tanah negara bebas atau tanah yang dikuasai langsung oleh Negara. Dari bunyi ketentuan mengandung makna bahwa hak guna usaha tidak boleh didirikan atas tanah Negara tidak bebas atau atas tanah hak, dalam arti terhadap tanah yang diatasnya telah terdapat kewenangan-kewenangan tidak boleh dijadikan obyek hak guna usaha, terlepas apakah haknya tersebut terdaftar atau belum terdaftar.

Persoalannya adalah bagaimana jika obyek hak guna usaha tersebut bukan tanah negara bebas, dalam arti terpaksa menggunakan tanah yang sudah ada haknya. Terhadap hal yang demikian maka tanah hak tersebut harus dijadikan tanah negara bebas terlebih dahulu, kemudian setelah tanah tersebut berada dalam penguaasaan langsung oleh negara baru bisa dijadikan sebagai obyek hak guna usaha. Hal ini sejalan dengan ketentuan bunyi Pasal 4 ayat (3) Peraturan Pemerintah Nomor 40 Tahun 1996, yang antara lain menyatakan bahwa pemberian hak guna usaha atas tanah yang telah dikuasai dengan hak tertentu, hak guna usaha baru dapat dilaksnakan setelah terselesaikannya pelepasan haknya menurut ketentuan yang berlaku.

Secara yuridis konseptual persoalan yang berkaitan dengan obyek hak guna usaha yang berasal dari tanah hak sepertinya tidak mengalami persoalan dan 
dibenarkan secara hukum sepanjang proses pelepasan hak atas tanah tersebut didasarkan pada peraturan yang berlaku. Akan tetapi manakalah prosedur tersebut tidak dilakukan secara benar menurut hukum, maka hal tersebut menjadi pemicu konflik antara pemegang hak semula dengan calon pemegang hak guna usaha atau pemegang hak guna usaha. Pengalaman di beberapa daerah termasuk di Provinsi Bengkulu yang menjadi penyebab konflik antara masyarakat dengan perusahaan perkebunan yang menggunakan fasilitas hak guna usaha salah satunya disebabkan karena masalah sengketa kepemilikan hak atas tanah tersebut, terutama berkaitan dengan ganti kerugian atas tanah dan tanam tumbuh atas tanah yang dilepaskan haknya pada masa-masa yang lalu.

Dalam praktek adakalanya dan mungkin banyak terjadi bahwa dalam proses pelepasan hak atas tanah yang telah dihaki oleh masyarakat oleh perusahaan perkebunan tidak dilakukan berdasarkan prosedur sebagaimana yang telah diatur dalam peraturan-perundangan. Dalam pelaksnaanya di lapangan tidak jarang pula menggunakan kekuasaan dan melibatkan apartur, mulai dari apatur ditingkat desa sampat kekuasaan tertinggi, tertuama pada era pemerintahan orde baru. Dalam proses pelepasan hak tersebut biasanya rakyat petani tidak mempunyai posisi tawar yang sama dengan pihak perusahaan, dan akibatnya rakyat banyak dirugikan, termasuk kehilangan sumber mata pencaharian pokok yang berupa lahan pertanian.

Konflik penguasaan tanah perkebunan yang terjadi akhir-akhir ini tidak jarang sebagai akibat proses pelepasan tanah hak yang terjadi pada masa yang lalu. Sebagaimana yang terungkap dalam Rapim Polri bulan Januari tahun 2013 yang menyatakan bahwa:

"Sengketa atau kasus di perkebunan pada umumnya adalah sengketa antara masyarakat di satu sisi dan perusahaan pemegang Hak Guna Usaha (HGU) di sisi lain, dalam bentuk penjarahan hasil perkebunan dan pendudukan tanah perkebunan dengan alasan untuk memenuhi kebutuhan hidup akibat dari desakan krisis ekonomi, sementara tanahtanah HGU tersebut dalam keadaan tidak ditanami atau memang disediakan untuk replantasi/peremajaan tanaman. Penjarahan atau pendudukan tanah perkebunan selain untuk pemenuhan kebutuhan hidup, juga yang terjadi dalam bentuk reclaiming action yaitu tuntutan pengembalian hak atas tanah leluhur atau tanah ulayat yang dianggap telah diambil untuk 
perkebunan dengan cara paksa, tanpa izin atau tanpa ganti rugi yang layak pada puluhan tahun yang lalu atau ada dugaan bahwa luas hasil ukur yang diterbitkan HGU berbeda dengan kenyataan di lapangan, sehingga tanah-tanah masyarakat masuk pada areal perkebunan ${ }^{6}$.

Dari kutipan tersebut yang ingin dijelaskan adalah bahwa, faktor yang sering menijadi pemicu konflik antara rakyat dengan perkebunan berpangkal pada tanah yang menjadi obyek hak guna usaha yang berasal sari tanah hak yang telah dimiliki oleh rakyat. Melihat fenomena ini seyogyanya pemerintah dalam hal ini instansi yang mempunyai kewenangan dalam memberikan izin penerbitan hak guna usaha tidak memberikan izin, apabila tanah yang akan menjadi obyek hak guna usaha tersebut adalah tanah-tanah yang masih dimiliki oleh rakyat. Izin pemberian hak guna usaha menurut hemat kami seyogyanya hanya diberikan terhadap tanah Negara yang benar-benar bebas, dalam artian di atas tanah tersebut belum ada kewenangan yang melekat sama sekali. Hal ini bukan saja untuk menghindari konflik penguasaan tanah perkebunan tetapi juga untuk menjaga agar distribusi tanah pertanian kepada rumah tangga pertanian tetap terjaga. Bukan tujuan program landreform adalah untuk memberikan akses yang lebih merata dalam penguasaan tanah pertanian kepada rumah tangga petani.

Berkaitan dengan luas maksimum penguasaan tanah yang dapat diberikan dengan status hak guna usaha, baik dalam UUPA, Peraturan Pemerintah Nomor 40 Tahun 1996, maupun dalam UndangUndang Nomor 18 Tahun 2004 Tentang Perkebunan. Dalam beberapa peraturan dimaksud hanya mengatur hak guna usaha yang subyeknya perorangan, dan untuk hak guna usaha yang subyek hukumnya badan hukum. Hal mana dapat disimak pada bunyi ketentuan Pasal 28 ayat (2) yang menyebutkan:

"Hak guna-usaha diberikan atas tanah yang luasnya paling sedikit 5 hektar, dengan ketentuan bahwa jika luasnya 25 hektar atau lebih harus memakai investasi modal yang layak dan teknik perusahaan yang baik, sesuai dengan perkembangan zaman".

Selanjutnya dalam Pasal 5 Peraturan Pemerintah Nomor 40 Tahun 1996 Tentang Hak Guna Usaha, Hak Guna Bangunan, dan Hak Pakai juga disebutkan bahwa:

1. Luas minimum tanah yang dapat diberikan Hak Guna Usaha

${ }^{6}$. Ibid. Hal 5. 
adalah lima hektar.

2. Luas maksimum tanah yang dapat diberikan Hak Guna Usaha kepada perorangan adalah dua puluh lima hektar.

3. Luas maksimum tanah yang dapat diberikan dengan Hak Guna Usaha kepada Badan Hukum ditetapkan oleh Menteri dengan memperhatikan pertimbangan dari pejabat yang berwenang di bidang usaha yang bersangkutan, dengan mengingat luas yang diperlukan untuk pelaksanaan suatu satuan usaha yang paling berdayaguna di bidang yang bersangkutan.

Demikian pula dalam Pasal 10 Undang-Undang Nomor 18 Tahun 2004

Tentang Perkebunan disebutkan bahwa:

1. Penggunaan tanah untuk usaha perkebunan, luas maksimum dan luas minimumnya ditetapkan oleh Menteri, sedangkan pemberian hak atas tanah ditetapkan oleh instansi yang berwenang di bidang pertanahan.

2. Dalam menetapkan luas maksimum dan luas minimum sebagaimana dimaksud dalam ayat (1), Menteri berpedoman pada jenis tanaman, ketersediaan tanah yang sesuai secara agroklimat, modal, kapasitas pabrik, tingkat kepadatan penduduk, pola pengembangan usaha, kondisi geografis, dan perkembangan teknologi.

3. Dilarang memindahkan hak atas tanah usaha perkebunan yang mengakibatkan terjadinya satuan usaha yang kurang dari luas minimum sebagaimana dimaksud dalam ayat (1).

4. Pemindahan hak atas tanah sebagaimana dimaksud dalam ayat (3) dinyatakan tidak sah dan tidak dapat didaftarkan.

Kutipan tersebut di atas menjelaskan bahwa, peraturan tersebut di atas hanya mengatur luas minimum tanah yang dapat diberikan hak guna usaha dan mengatur juga luas maksimum tanah hak guna usaha perorangan. Akan tetapi luas maksimum untuk tanah hak guna usaha yang subyeknya perusahaan tidak diatur secara jelas. Dalam ketiga peraturan tersebut dirumuskan secara kabur yaitu seperti memberi justifikasi yang didasarkan pada kondisi suatu perusahaan, baik dari segi permodalan, teknologi, dan lain-lain pertimbangan yang penilaian kelayakan tersebut diserahkan kepada instansi teknis yang membidangi usaha tersebut, seperti instansi perkebunan.

Ketentuan tersebut mengandung makna bahwa, apabila secara teknis perusahaan tersebut dianggap layak oleh pejabat teknis yang membidangi usaha tersebut, maka tidak ada alasan untuk tidak mengabulkan izin perkebunan berapapun luasnya tanah yang menjadi obyek hak guna usaha yang dimohonkan. 
Cara penentuan luas maksimum seperti ketentuan tersebut menurut hemat kami ada kecendrungan dapat disalahgunakan oleh pejabat yang ditunjuk untuk memberikan pertimbangan untuk bertindak secara tidak obyektif. Bahkan ketentuan tersebut memberi peluang bagi pihak-pihak yang berkepentingan untuk melakukan perbuatan yang menyimpang seperti kolusi, korupsi, dan nepotisme.

Dalam praktek pelakasnaan ketentuan tersebut terindikasi terdapat penyimpangan yang tentunya tidak sesuai dengan kehendak peraturan tersebut. Hal ini dapat terjadi disebabkan karena selain adanya unsur subyektif pihak-pihak yang berkepentingan yang akibatnya terjadi kolusi, menurut dugaan saya para pejabat yang memberi pertimbangan hanya melihat dari sisi teknis perusahaan belaka tetapi tidak memahami filosofi pengaturan tanah sebagaimana yang dimaksud dalam UUPA.

Seyogyanya berdasarkan fakta yang terjadi di masyarakat, dimana maslah penguasaan tanah pertanian semakin tidak adil, konflik rakyat dengan perkebunan semakin hari menunjukkan pada eskalasi yang meningkat baik dari kwantitas maupun kwalitas konflik, adalah sudah seyogyanya menata kembali peraturan yang berkaitan dengan luas maksimum tanah yang boleh dimiliki dengan hak guna usaha. Dengan cara reregulasi peraturan tentang luas hak guna usaha dalam bentuk peraturan. Dengan demikian akan terwujud kepastian hukum (hukum dalam arti perundang-undangan) dalam pemberian izin hak guna usaha. Bukankah tujuan dari dibentuknya UUPA dalam rangka memberikan kepastian hukum.

\section{Terlantarnya Tanah Hak Guna Usaha Secara Fisik}

Sebagaimana yang telah dijelaskan pada uraian terdahulu, bahwa sebagai akibat tidak ada pengaturan yang jelas mengenai luasan maksimum tanah hak guna usaha yang subyek hukumnya badan hukum ditambah lagi dengan argumentasi memberikan fasilitas bagi investasi dalam rangka pertumbuhan ekonomi menjadi alasan bagi pemerintah untuk memberikan izin hak guna usaha kepada perusahaan perkebunan tanpa memperhatikan berapa luas tanah yang dimohonkan oleh perusahaan perkebunan dimaksud.

Implikasi hukumnya adalah timbul penguasaan tanah sangat luas yang 
dimiliki oleh perusahaan perkebunan dengan status kepemilikan hak guna usaha. Sebagai contoh di Provinsi Bengkulu, sampai dengan saat ini tercatat paling tidak ada sekitar 37 perusahaan yang yang menguasi tanah dengan hak guna usaha yang menguasai lahan ribuan hektar. Jika dilihat dari peruntukkan tanah hak guna usaha tersebut, pada umumnya tanah hak guna usaha di Provinsi Bengkulu diperuntukkan bagi usaha perkebunan seperti kelapa sawit, karet, dan perkebunan kakao. Dari jumlah tersebut sekitar 25 hak guna usaha yang masih aktif dan selebihnya tidak aktif dan bahkan sudah dicabut izin hak guna usahanya.

Luasnya lahan hak guna usaha yang diberikan dengan prosedur dan alas hak yang sesuai dengan peraturan perundangundangan dan hak guna usaha itu sendiri dikelola secara baik sesuai dengan peruntukkannya, sudah barang tentu akan menimbulkan manfaat dalam meningkatkan pertumbuhan ekonomi suatu daerah dan Negara. Tetapi manakalah hak guna usaha yang begitu luas tersebut tidak dikelola dengan baik sesuai dengan peruntukkan hak guna usaha dimaksud serta dibiarkan "terlantar secara fisik", maka bukan saja akan merugikan Negara secara ekonomi karena tujuan dari pemberian izin investasi tersebut tidak menghasilkan pertumbuhan ekonomi tetapi juga dapat menimbulkan konflik dengan rakyat disekitar perkebunan tersebut. Hasil identifikasi Badan Pertanahan Nasional mengenai tanah terlantar menunjukkan bahwa pada tahun 2008 secara nasional tercatat seluas 7.386.289 Hektar tanah dengan bermacam status hak dinyatakan sebagai tanah terlantar. Dari jumlah tersebut yang terluas adalah tanah dengan status kepemilikan Hak Guna Usaha yaitu seluas 1.925.326 Hektar ${ }^{8}$. Data tersebut menunjukkan pula bahwa pemberian hak guna usaha yang begitu luas dan ditambah pula dengan prosedur pemberian hak guna usaha yang tidak selektif menjadikan hak guna usaha sebagai penyebab yang potensial luasnya tanah terlantar.

Mengenai istilah tanah terlantar

\footnotetext{
${ }^{7}$ Mengenai istilah tanah terlantar kami membedakan antara tanah terlantar secara fisik dan tanah terlantar secara yuridis. Tanah terlantar secara fisik adalah tanah hak guna usaha yang tidak dikelola sesuai dengan peruntukkan pemberian izin hak guna usaha tersebut. Sementara tanah terlantar secara yuridis adalah tanah yang telah hak yang telah ditetapkan sebagai tanah terlantar menurut peraturan perundang-undangan yang berlaku.

${ }^{8}$ Noer Fauzi Rachman, "Refleksi Perjalanan Reforma Agraria 2005-2009" dalam Widiyanto dan Siti Rakhma Mary, (ed), Refleksi Perjalanan Kembalinya TAP MPR NO. IX Tahun 2001 Tentang Pembaruan Agraria dan Pengelolaan Sumber Daya Alam.
} 
kami membedakan antara tanah terlantar secara fisik dan tanah terlantar secara yuridis. Tanah terlantar secara fisik adalah tanah hak yang secara faktual tidak dikelola secara fisik, seperti membiarkan tanah tidak terawat dengan baik atau membeiarkan tanah menjadi tidak produktif. Sementara tanah terlantar secara yuridis adalah tanah hak yang berdasarkan kreteria tertentu telah ditetapkan secara hukum sebagai tanah terlantar menurut peraturan perundangundangan yang berlaku.

Berkaitan konsep tanah terlantar ini Suhariningsih ${ }^{9}$ menyatakan, bahwa kejelasan konsep hukum tanah terlantar yang ada, dijumpai dua istilah tanah terlantar dan tanah ditelantarkan. Konsep tanah terlantar lebih tepat dipakai untuk menyatakan keadaan fisik sebidang tanah; a. tidak dipergunakan sesuai dengan keadaannya, b. tidak dipergunakan sesuai dengan sifat dan tujuan haknya, c. tanah tidak dipelihara dengan baik. Konsep tanah ditelantarkan lebih menekankan pada perbuatan pemegang hak atas tanah yang sengaja menelantarkan tanah sehingga tanah menjadi terlantar. Dalam hal ini perbuatan menelantarkan tanah

${ }^{9}$ Suhariningsih, Tanah Terlantar, Asas dan Pembaharuan Konsep Menuju Penertiban, Prestasi Pustaka Publisher, Jakarta, 2009, hal 303-304. harus dibuktikan terlebih dahulu dengan meneliti keadaan fisik dan kreterianya. Pendapat ini nampaknya membedakan antara tanah terlantar dan tanah ditelantarkan. Tanah terlantar dimaksudkan untuk menunjuk tanah terlantar secara fisik, sementara tanah ditelantarkan mengindikasikan sebagai tanah terlantar secara yuridis, karena yang terakhir ini terdapat kreteria tertentu dan aktifitas yang dilakukan oleh instansi yang berwenang untuk menyatakan sebagai tanah ditelantarkan.

Dengan demikian terdapat perbedaan antara tanah terlantar secara fisik dan tanah terlantar secara yuridis. Tanah terlantar secara fisik tidak serta merta menyebabkan tanah tanah tersebut terlantar secara yuridis. Terhadap tanah terlantar secara fisik diatas tanah tersebut masih terdapat kewenangan-kewenangan yang melekat pada pemegang haknya. Hal tersebut berbeda dengan tanah terlantar secara yuridis, dengan ditetapkannya tanah tersebut sebagai tanah terlantar maka hubungan hukum antara subyek hukum dan obyek hukum tersebut menjadi terputus, terutama untuk hak guna usaha. Dalam arti hak pemegang hak guna usaha tersebut menjadi hapus dan tanahnya jatuh kepada Negara. 
Beberapa faktor yang menjadi penyebab tanah perkebunan terlantar secara fisik. Pertama, terbatasnya modal investor pemegang hak guna usaha sementara lahan yang dimiliki terlalu luas. Faktor ini menjadi kendala didalam melaksanakan usaha perkebunan. Faktor ini tidak boleh terjadi manakala didalam memberikan izin hak guna usaha didasarkan pada tata cara sebagaimana aturan yang berlaku. Kedua, pengalihan modal pada sektor bisnis yang lebih menguntungkan. Caranya adalah menjadikan hak guna usaha sebagai agunan dalam memperoleh fasilitas kredit dari Bank. Kemudian uang pinjaman tersebut dialihkan kesektor bisnis yang lain seperti property di kota-kota besar. Akibatnya tanah yang diperoleh dengan fasilitas hak guna usaha menjadi terlantar. Tanah terlantar yang terakhir inilah kami sebut sebagai tanah yang ditelantarkan.

Berdasarkan fakta empiris salah satu penyebab terjadinya konflik antara rakyat dan perkebunan ditimbulkan karena adanya penelantaran secara fisik oleh pemegang hak guna usaha perkebunan. Dengan penelantaran tanah tersebut membuka peluang bagi rakyat untuk menguasai tanah perkebunan dimaksud. Terdapat dua modus operandi rakyat menguasai tanah perkebunan:

Pertama; Rakyat baik sendirisendiri maupun bersama-sama, secara individu maupun berkelompok secara illegal mulai melakukan penggarapan terhadap tanah perkebunan tersebut. Cara ini biasanya dilakukan oleh masyarakat yang berada disekitar perkebunan. Mereka mulai membuka lahan, bercocok tanam seperti menggarap tanahnya sendiri. Mula-mula yang ditanam adalah tanaman semusim, seperti palawija, sayur-sayuran yang tentunya bukan tanaman keras. Dalam aksinya mereka mendapat hambatan dari perusahaan perkebunan. Menghadapi kendala yang demikian biasanya mereka berlindung dengan menggunakan istilah menumpang untuk menanam bukan tanaman keras, dengan jaminan apabila perusahaan akan membuka lahan tersebut para penggarap akan memberikan tanah tersebut secara sukarela. Jika hal ini dibiarkan oleh perusahaan perkebunan, maka komuditas yang ditanam bukan lagi hanya sekedar tanaman semusim tetapi meningkat menjadi tanaman keras, seperti karet, kelapa sawit dan lain-lain. Apabila ini terjadi maka ketika perusahaan ingin menggunakan tanah untuk keperluan hak guna usahanya, biasanya akan terkendalah 
oleh perosalan ganti kerugian atas tanam tumbuh di atas tanah tersebut. Selanjutnya cara ini semakin lama semakin meluas, bukan saja dilakukan oleh rakyat sekitar perkebunan, melainkan mulai melibatkan masyarakat pendatang. Fakta juga menunjukkan kadang-kadang bukan hanya petani, melainkan dilakukan oleh bukan petani dan mempunyai keududukan yang penting dan berpengaruh di suatu daerah, bahkan tidak janrang juga mereka menjadi pemodal yang berperan dibalik petani-petani tersebut.

Kedua, Rakyat menguasai tanah perkebunan didasarkan pada suatu perbuatan hukum, seperti transaksi jual beli kepada oknum warga desa sekitar. Hal ini terjadi karena ada oknum warga desa setempat mengaku sebagai pemilik lahan tersebut. Kadang-kadang transaksi ini mendapat legitimasi aparatur pemerintah desa seperti Kepala Desa, dengan cara memberikan Surat Keterangan Tanah (SKT) atas tanah, yang sesungguhnya milik perusahaan perkebunan. Cara ini biasanya ditujukan kepada petani yang bukan berasal dari daerah tersebut yang notabene tidak menguasai informasi mengenai status tanah yang menjadi obyek jual-beli. Cara seperti ini banyak dijumpai dibeberapa daerah yang ada di Provinsi Bengkulu.

\section{Tumpang Tindih Kepemilikan Tanah}

Selain masalah yang telah diuraikan sebelumnya, hal lain menjadi pemicu konflik antara masyarakat dengan perusahaan perkebunan yaitu berkaitan dengan adanya tumpang tindih kepemilikan lahan. Kondisi ini terjadi karena batas antara hak guna usaha perkebunan dan tanah petani tidak akurat. Sehingga masing-masing mengklaim sebagai pemilik tanah yang dimaksud. Hal ini sesungguhnya tidak boleh terjadi manakala dalam proses penerbitan sertifikat tanah hak guna usaha benarbenar dilakuan sesuai dengan ketentuan yang berlaku. Boleh jadi masyarakat mungkin belum mempunyai bukti-bukti tertulis seperti sertifikat, akan tetapi seyogyanya pada saat melakukan pengukuran, termasuk penentuan batasbatas hak guna usaha semestinya masyarakat yang mempunyai tanah berbatasan dilibatkan dalam kegiatan ini. Inilah sesungguhnya hakikat dari tujuan pendaftaran tanah adalah untuk menciptakan kepastian hukum bagi pihakpihak yang berkepentingan dan kepastian hak bagi pemilik tanah. Dengan demikian 
maka tujuan pendaftaran tanah tidak hanya berorientasi pada tertib administrasi tetapi juga tertib hukum.

Beberapa masalah sebagaimana yang telah dijelaskan sebelumnya merupakan pertanahan yang klasik, sangat serius dan harus segera diakhiri. Bermula dari tingginya angka kebutuhan lahan pertanian bagi petani sebagai akibat pertambahan penduduk, tidak adanya keadilan dalam distribusi tanah pertanian kepada petani, adanya ketimpangan penguasaan tanah pertanian yang dimiliki baik oleh perorangan maupun oleh perusahaan perkebunan, sampai pada masalah ketidakpastian hukum atas penguasaan dan pemilikan tanah pertanian seperti tumpang tindih pemilikan tanah antara rakyat dengan perusahaan perkebunan telah menimbulkan konflik sosial yang berkepanjangan.

Konflik tanah perkebunan tersebut tidak hanya sekedar konflik sosial sematamata yaitu hanya berkaitan dengan penguasaan tanah perkebunan semata, dalam arti adanya keinginan masyarakat untuk menguasai tanah perkebunan, melainkan telah meningkat pada masalah ketertiban hukum. Sebagaimana sinyalemen tersebut terungkap dalam Rapim Polisi Republik Indonesia yang diselenggarakan di Jakarta pada bulan Januari 2013 antara lain menyatakan:

"Konflik yang terjadi di perkebunan khususnya adalah berkaitan dengan permasalahan tanah yang mengarah kepada konflik horisontal antara perkebunan dengan masyarakat penggarap dan telah mengakibatkan tindak kekerasan berbentuk pengrusakan lahan (tanah) dan tanaman perkebunan, kemudian bentrok fisik karyawan perkebunan dengan para petani yang menduduki lahan perkebunan, dengan kata lain lingkungan perkebunan telah mengalami kerusakan. Selanjutnya dinyatakan bahwa, konflik antara rakyat dan perkebunan telah dirasakan dampaknya terhadap lingkungan kerja, terhadap investasi maupun penerimaan Negara. Pendudukan tanah-tanah perkebunan oleh masyarakat secara paksa telah mengakibatkan rusaknya lingkungan hidup, konflik antara masyarakat dan karyawan perkebunan, mengganggu ketenangan dan keamanan kerja, pada lingkungan kerja perkebunan tersebut. Tidak adanya rasa aman dan ketenangan dalam bekerja lebih lanjut mengakibatkan hasil-hasil perkebunan yang belum layak panen terpaksa di panen lebih awal untuk menghindari dari penjarahan. Dengan demikian ia menghasilkan produk yang berkualitas rendah sehingga tidak mampu bersaing di pasar internasional. Hal ini secara akumulatif berdampak terhadap penerimaan Negara dan pembangunan nasional. Perusahaan Perkebunan dalam mengelola usaha perkebunan 
terpaksa harus menghadapi permasalahan konflik tanah hak guna usahanya dengan masyarakat yang melakukan penggarapan di dalam areal lahan perkebunan berdasarkan atas Hak Guna Usaha (HGU). ${ }^{10}$.

Konflik antara rakyat dan perkebunan yang semula merupakan konflik horizontal antara rakyat dan perusahaan perkebunan, telah meningkat menjadi masalah hukum dan kriminal, yang apabila tidak segera dicarikan penyelesaiannya akan mempunyai dampak yang lebih serius lagi mulai dari kerugian secara ekonomi tetapi juga akan menciptakan suatu mayarakat yang tidak tertib (disorder).

Persoalannya sekarang adalah bagaimana mencari solusi penyelesaian konflik yang sedang terjadi saat ini, khususnya di sektor perkebunan lebih tegasnya adalah HGU. Memang untuk mencari cara penyelesaian konflik tersebut tentunya bukan suatu hal yang gampang dan mungkin justru akan menimbulkan masalah baru. Apalagi jangka waktu HGU tersebut masih panjang. Akan tetapi bukan berarti tidak ada cara sama sekali.

Apabila kita merujuk kepada Pasal 1 huruf d PP No. 224 tahun 1961 yang

\footnotetext{
${ }^{10}$ Op.Cit. Hal 4.
}

antara lain menyatakan: "Tanah-tanah yang dalam rangka pelaksanaan landreform akan dibagikan menurut ketentuan dalam peraturan ini ialah......tanah-tanah yang dikuasai langsung oleh negara yang akan ditegaskan lebih lanjut oleh Menteri Agraria”. Selanjuntnya pada penjelasan ketentuan pasal tersebut disebutkan bahwa: "tanah-tanah lain yang dikuasai langsung oleh negara, yang akan ditegaskan lebih lanjut, misalnya bekas tanah-tanah partikelir, tanah-tanah dengan hak guna usaha yang telah berakhir waktunya, dihentikan atau dibatalkan, tanah-tanah kehutanan yang telah diserahkan kembali oleh penguasaannya...".

Berpangkal pada pendirian pasal tersebut khususnya terhadap HGU yang telah berakhir jangka waktunya atau sebentar lagi akan habis masa waktunya ditetapkan sebagai tanah obyek landreform yang untuk seterusnya diredistribusikan kepada petani. Paling tidak terhadap HGU yang rentan terhadap konflik. Atau dengan perpanjangan HGU tetapi dengan persyaratan-persyaratan khusus.

Mengacu kepada UUPA khususnya Pasal 7 dan UU No.56 Prp tahun 1960 
mengenai luas maksimum tanah pertanian, kiranya perlu ditetapkan batas atau luas maksimum HGU yang boleh dimiliki. Meskipun dalam ketentuan tersebut tidak ada pembatasan. Selanjutnya terhadap HGU yang luasnya melebihi celling ditetapkan sebagai tanah obyek landreform yang kemudian diredistribusikan kepada petani yang memenuhi syarat. Ketentuan ini diperuntukkan bagi pemberian HGU yang baru dan HGU yang waktunya masih berlangsung. Perlunya pembatasan luas maksimun HGU saat ini menurut saya sudah merupakan suatu hal yang sangat mendesak.

Asumsi saya sangatlah tidak beralasan bahwa perusahaan perkebunan harus mempunyai lahan HGU yang sangat luas. Bagi perusahaan bukan luas lahan yang menjadi tujuan utama, melainkan hasil dari tanaman perkebunan itu, seperti buah tandan segar untuk kelapa sawit, atau getah dari karet yang kemudian untuk diolah lebih lanjut menjadi bahan setengah jadi. Kalau asumsi ini benar maka, perusahaan perkebunan cukup menguasai HGU yang tidak begitu luas misalnya 100 hektar tiap perusahaan, kemudian untuk menambah luasan tersebut perusahaan bisa saja menggunakan tanah masyarakat dengan pola kemitraan dengan bermacam-macam skema dan instilah yang berbasis hukum lokal seperti surungan, sorong atau Kebun Masyarakat Desa, dengan perjanjian hasil dari kebun rakyat nanti akan dijual kepada perusahaan. Dengan skema ini maka akan terwujud kerjasama yang saling menguntungkan (simbosis mutualisme) dalam bidang perkebunan.

Hasil penelitian Emelia Kontesa membuktikan bahwa pola kemitraan dalam penyelenggaraan usaha perkebunan antara masyarakat lokal dengan perusahaan perkebunan merupakan kemitraan saling bersinergi dan saling menguntungkan, baik bagi pemerintah, perusahaan perkebunan, maupun masyarakat lokal ${ }^{11}$.

Dengan cara ini menurut pemikiran saya merupakan salah satu alternatif penyelesaian konflik. Keuntungan bagi perusahaan (pemegang HGU) dapat menghindari dari kerugian yang lebih besar serta menciptakan iklim yang aman bagi investasinya. Bagi petani disekitarnya akan dan berkewajiban ikut menjaga perusahaan tersebut terutama

\footnotetext{
${ }^{11}$ Emelia Kontesa, Penyelenggaraan Usaha Perkebunan Berbasis Pranata Hukum Masyarakat Lokal Untuk Sebesar-besar Kemakmuran Rakyat, "Disertasi", Program Doktor Ilmu Hukum Fakultas Hukum Universitas Brawijaya, Malang, 2012. Hal. 370
} 
dari kerusakan, karena mereka memiliki asset tersebut. Dalam konsep ini petani lokal tetap sebagai pemilik lahan pertanian, sementara perusahaan sebagai mitra yang dalam perjanjiann kemitraan tersebut sebagai pihak yang mempunyai hak dan kewajiban, seperti kewajiban melakukan pembinaan terhadap petani dan berhak atas hasil dari tanaman tersebut sesuai dengan isi perjanjian.

Banyak kasus yang terjadi di daerah, keberadaan perusahan perkebunan belum terlihat dapat memberikan dampak yang positif bagi peningkatan kesejahteraan petani di sekitar perkebunan. Perusahaan perkebunan yang mempunyai luas HGU yang sangat luas justru telah menjadikan masyarakat petani disekitar perkebunan menjadi kelihangan tanah pertanian, karena obyek HGU yang dimiliki oleh perusahaan perkebunan adalah tanah Negara yang berasal dari pelepasan hak atau pembebasan hak atas tanah yang dimiliki petani. Sehingga tidak mengherankan jika keberadaan perusahaan perkebuna telah merubah status rumah tangga petani dari petani pemilik menjadi buruh tani. Oleh karena itu dengan konsep kemitraan yang dibangun dalam usuha perkebunan secara benar, apalagi kalau kemitraan tersebut dibangun berdasarkan pranata hukum lokal, dapat dipastikan tidak akan terjadi konflik antara rakyat dan perusahaan perkebunan. Konsep ini sering saya sebagai konsep membangun tanpa menggusur. Dengan konsep ini diyakini bahwa akses petani terhadap tanah pertanian semakin lama semakin baik. Karena keberadaan investasi disektor perkebunan besar tidak akan menyebabkan para petani terpinggirkan, bahkan justru sebaliknya akan dapat memberikan manfaat bagi petani sekitar perusahaan perkebunan tersebut. Dengan pola kemitraan misalnya maka dapat diyakini secara ekonomis kondisi petani akan semakin lama semakin meningkat, demikian juga dengan perusahaan perkebunan tentunya akan dapat melaksnakan investasinya dengan kondusif.

\section{Penutup}

Bagian akhir dari tulisan ini, ingin dijelaskan bahwa penyelesaian konflik pertanahan yang begitu banyak secara kwantitas maupun ragamnya memerlukan kehati-hatian serta keseriusan dari semua pihak khususnya penguasa. Sebab jika tidak hati-hati justru kemungkinan akan menimbulkan konflik selanjutnya. Demikian 
juga dalam hal menentukan kebijakan penyelesaian konflik tersebut hendaknya didahului dengan suatu studi yang mendalam sehingga kebijakan yang diputuskan dapat memenuhi sasaran. Sebab persoalan tanah saat ini bukan hanya persoalan hak atas tanah semata melainkan persoalan yang multikompleks dan mempuyai banyak aspek. Oleh karena itu dalam menyelesaikan konflik pertanahan juga harus didekati dari beberapa sudut padang, tidak hanya pendekatan hukum formal semata-mata tetapi juga dilakukan melalui pendekatan-pendekatan lain seperti ekonomi, budaya, dan sosial.

\section{DAFTAR PUSTAKA}

Badan Pusat Statistik, Laporan Hasil Sensus Pertanian Tahun 2013Badan Pembinaan Hukum Nasional. Seminar Hukum Adat Dan Pembinaan Hukum Nasional. Jakarta: Bina Cipta, 1976.

Boeni Setiawan. "Konsep pembaruan Agraria Sebuah Tinjauan Umum”, dalam Dianto Bachriadi, Erfan Faryadi, dan Bonie Setiawan, ed. Reformasi Agraria. Jakarta: KPA-LPFE-UI, 1997, hal. 3-50.
Emelia Kontesa, Penyelenggaraan Usaha Perkebunan Berbasis Pranata Hukum Masyarakat Lokal Untuk Sebesar-besar Kemakmuran Rakyat, "Disertasi", Program Doktor Ilmu Hukum Fakultas Hukum Universitas Brawijaya, Malang, 2012.

Keputusan Kepala Badan Pertanahan Nasional Republik Indonesia, Keputusan Kepala Badan Pertanahan Nomor 34 Tahun 2007 Tentang Petunjuk Teknis Penanganan dan penyelesaian Masalah Pertanahan.

Noer Fauzi Rachman, "Refleksi Perjalanan Reforma Agraria 2005-2009" dalam Widiyanto dan Siti Rakhma Mary, (ed), Refleksi Perjalanan Kembalinya TAP MPR NO. IX Tahun 2001 Tentang Pembaruan Agraria dan

Rapim Polri, Identifikasi Potensi Konflik Yang Bersumber Dari Sara, Industri, Economy Gap, Masalah Ketenagakerjaan Dan Dampak Industri Perkebunan Serta Upaya Penanggulangannya Secara Efektif, "Makalah", Jakarta, 30 Januari 2013.

Suhariningsih, Tanah Terlantar, Asas dan Pembaharuan Konsep Menuju Penertiban, Prestasi Pustaka Publisher, Jakarta, 2009.. 